\title{
KEBERLAKUAN NORMATIF KETENTUAN PIDANA UNDANG-UNDANG NOMOR 11 TAHUN 2016 TENTANG PENGAMPUNAN PAJAK
}

\author{
Oleh: \\ Hernawan, Mihwar Anshari \\ Fakultas Hukum Universitas Airlangga \\ E-mail: nawan.djp@gmail.com, erwan.khan@gmail.com
}

\begin{abstract}
Abstrak
Pada Tahun 2016, Pemerintah Indonesia membuat kebijakan pengampunan pajak dengan memakai instrumen undang-undang sebagai dasar hukumnya, yaitu Undang-undang Nomor 11 Tahun 2016 tentang Pengampunan Pajak. Pemerintah Indonesia membuat kebijakan pengampunan pajak karena pertumbuhan ekonomi nasional dalam beberapa tahun terakhir mengalami perlambatan, dan karena banyak harta Warga Negara Indonesia yang ditempatkan di luar wilayah Indonesia. Kebijakan Pengampunan Pajak dilakukan dalam bentuk pelepasan hak negara untuk menagih pajak yang seharusnya terutang. Oleh karena itu, sudah sewajarnya jika Wajib Pajak diwajibkan untuk membayar Uang Tebusan atas Pengampunan Pajak yang diperolehnya. Hasil penelitian menunjukkan bahwa keberlakuan sanksi pidana dalam Undang-undang Nomor 11 Tahun 2016 tentang Pengampunan Pajak setelah tanggal 31 Maret 2017 tidak berlaku. Hal ini sesuai dengan asas perubahan perundang-undangan sebagaimana diatur dalam Pasal 1 ayat (2) KUHP. Sedangkan implikasi Ketentuan Pidana Undang-undang Nomor 11 Tahun 2016 tentang Pengampunan Pajak terhadap Penyidikan Tindak Pidana Pencucian Uang, yang berlaku ialah ketentuan pidana yang diatur dalam UU Nomor 8 Tahun 2010 tentang Pencegahan dan Pemberantasan Tindak Pidana Pencucian Uang, karena mengatur lebih lengkap dan rinci dalam kerangka ketentuan pidana khusus. Hal ini diperkuat oleh Putusan Mahkamah Konstitusi Nomor 57/PUU-XIV/2016 tentang Uji Materi Undang-undang Nomor 11 Tahun 2016 tentang Pengampunan Pajak, yang menyatakan bahwa Undang-undang Nomor 11 Tahun 2016 tidak membebaskan peserta Pengampunan Pajak dari sanksi hukum lain di luar sanksi administrasi perpajakan dan sanksi pidana di bidang perpajakan.
\end{abstract}

Kata kunci: Ketentuan Pidana, Pengampunan Pajak, Tindak Pidana Pencucian Uang

\section{A. PENDAHULUAN}

Sejarah pemungutan pajak mengalami perkembangan dari masa baik di bidang kenegaraan maupun di bidang sosial dan ekonomi. ${ }^{1}$ Pajak pada mulanya merupakan suatu upeti, yaitu merupakan suatu kewajiban yang dapat dipaksakan

1 Erly Suandy, 2014, Hukum Pajak, Salemba Empat, Jakarta, hlm. 1. 
dan harus dilaksanakan oleh rakyat. Ketika itu, rakyat memberikan upetinya kepada penguasa dalam bentuk natura berupa ternak atau hasil tanam. Pemberian yang dilakukan rakyat saat itu digunakan untuk keperluan penguasa. ${ }^{2}$ Perkembangan masyarakat hingga membentuk suatu negara melatarbelakangi dibuatnya suatu aturan berupa undang-undang yang mengatur tentang tata cara pemungutan pajak, jenis-jenis pajak, pihak yang harus membayar pajak, serta besarnya pajak yang harus dibayar. ${ }^{3}$

Dalam Undang-Undang Dasar 1945 (hasil amandemen) pajak diatur di dalam Pasal 23A. Jadi setiap pajak yang dipungut oleh pemerintah harus berdasarkan undang-undang, sehingga tidak mungkin ada pajak yang hanya dipungut berdasarkan keputusan pemerintah atau dengan peraturan lain yang lebih rendah lainnya. ${ }^{4}$

Undang-undang Nomor 6 Tahun 1983 (Undang-Undang KUP), merupakan hukum formal dalam bidang pajak. Sebagai hukum formal, maka undang-undang tersebut diciptakan untuk melaksanakan hukum pajak materiil. Di dalam sistem hukum pajak yang berlaku sekarang digunakan model pengaturan bahwa hukum pajak formal digunakan untuk melaksanakan semua hukum pajak materiil. Model pengaturan ini agak berbeda dengan sebelum adanya pembaharuan perpajakan nasional tahun 1983, yang pada waktu itu setiap undang-undang pajak di dalamnya sudah mencakup hukum pajak materiil dan hukum pajak formal sekaligus. Jadi model pengaturannya berpasang-pasangan. Ada sejumlah hal dalam UU KUP yang perlu untuk mendapatkan kajian berkait dengan keadilan. Beberapa hal tersebut misalnya menyangkut Pengampunan Pajak, pengajuan keberatan, pengajuan banding, mengenai rahasia Wajib Pajak, termasuk juga mengenai sanksi. ${ }^{5}$

Insentif perpajakan, baik berupa pembebasan pajak, keringanan pajak, penyusutan yang dipercepat dan sebagainya beda dengan Pengampunan Pajak (tax amnesty) yang beberapa tahun ke belakang muncul perdebatan dan sampai

2 Wirawan B. Ilyas dan Richard Burton, 2014, Hukum Pajak: Teori, Analisis, dan Perkembangannya, Salemba Empat, Jakarta, hlm. 1.

3 Ibid., hlm. 2.

4 Rochmat Soemitro dan Dewi Kania Sugiharti, 2004, Asas dan Dasar Perpajakan 1, Refika Aditama, hlm. 7.

5 Y. Sri Pudyatmoko, 2015, Memahami Keadilan di Bidang Pajak, Cahaya Atma Pustaka, Yogyakarta, hlm. 15. 
sekarang menjadi kontroversi. Dalam sejarah pajak di Indonesia, Pengampunan Pajak telah dilakukan dua kali, yaitu berdasarkan Penetapan Presiden Nomor 5 Tahun 1964 dan berdasarkan Keputusan Presiden Nomor 26 Tahun 1984 tentang Pengampunan Pajak. ${ }^{6}$

Pada tahun 2016, Pemerintah Indonesia mengambil kebijakan Pengampunan Pajak, yang menggunakan undang-undang sebagai dasar hukumnya, yaitu Undang-Undang Nomor 11 Tahun 2016 tentang Pengampunan Pajak. Yang menjadi permasalahan ialah Undang-Undang Pengampunan Pajak menimbulkan terjadinya konflik hukum, yaitu Undang-Undang Pengampunan Pajak ini bertabrakan dengan Undang-Undang Tindak Pidana Pencucian Uang. Dalam perspektif hukum pidana, undang-undang ini melegalkan tindak pidana pencucian uang karena undang-undang ini melindungi Wajib Pajak yang menyembunyikan uangnya baik di dalam negeri maupun di luar negeri yang diperoleh dari hasil korupsi, narkotika, dan tindak pidana lainnya. Dengan tanpa melihat asal usul harta tersebut, setelah Wajib Pajak mengungkapkan uangnya dan mendapatkan surat keterangan telah mengikuti Pengampunan Pajak dari Menteri Keuangan, maka atas uang tersebut dinyatakan legal dan berhak direpatriasi tanpa ada penegakan hukum. Hal ini diatur dalam Pasal 20 UndangUndang Pengampunan Pajak.

Berdasarkan Pasal 20 UU Pengampunan Pajak, maka Wajib Pajak yang mengungkapkan harta atau uangnya yang berasal dari pidana pencucian uang akan bebas dari proses penegakan hukum, yaitu tidak dapat dilakukan penyelidikan, penyidikan, dan penuntutan pidana baik oleh pihak Kepolisian, Kejaksaan, maupun KPK. Hal ini dipertegas lagi dalam Pasal 21 ayat (3). Keberadaan Pasal 20 dan Pasal 21 ayat (3) Undang-Undang Pengampunan Pajak ini bertentangan dengan semangat pemberantasan tindak pidana pencucian uang yang diatur dalam Undang-Undang Nomor 8 Tahun 2010 tentang Pencegahan dan Pemberantasan Tindak Pidana Pencucian Uang, yaitu semangat dalam upaya mencegah dan memberantas tindak pidana pencucian uang secara lebih efektif, karena tindak pidana pencucian uang sangat merugikan keuangan atau perekonomian negara dan menghambat pembangunan nasional.

6 Ibid. 
Selanjutnya Ketentuan Pasal 21 ayat (2) UU Pengampunan Pajak bertentangan dengan prinsip keterbukaan informasi dan transparansi yang dianut oleh peraturan perundang-undangan Indonesia, sebab dengan adanya ketentuan Pasal 21 ayat (2) ini, maka terhadap aparat pajak yang mengetahui harta Wajib Pajak yang berasal dari hasil tindak pidana pencucuian uang, tidak boleh memberitahukan atau melaporkan kepada aparat penegak hukum. Bahkan yang lebih jauh lagi, terhadap orang yang melanggar Pasal 21 ayat (2) ini diancam dengan pidana penjara paling lama 5 (lima) tahun. Hal ini diatur dalam Pasal 23 ayat (1) UU Pengampunan Pajak.

Permasalahan berikutnya ialah masa berlakunya UU Pengampunan Pajak yang dibatasi masa berlakunya, yaitu hanya berlaku sampai dengan Maret 2017. Hal ini tentunya akan menimbulkan konsekuensi hukum yang diantaranya dalam hal ketentuan pidana baik dilihat dari berlaku atau tidaknya ketentuan pidana tersebut dan bagiaman proses hukumnya apabila terjadi tindak pidana sebagaimana diancam dalam Pasal 23 ayat (1) setelah masa berlaku UU Pengampunan Pajak berakhir.

\section{B. METODE PENELITIAN}

Penelitian ini merupakan suatu penelitian hukum normatif yang dilakukan untuk mencari pemecahan masalah atas permasalahan hukum yang ada. Hasil dari penelitian ini adalah memberikan preskripsi mengenai apa yang seyogyanya dilakukan. Penelitian hukum (legal reseach) adalah menemukan kebenaran koherensi, yaitu adakah aturan hukum sesuai norma hukum dan adakah norma yang berupa perintah atau larangan itu sesuai dengan prinsip hukum, serta apakah tindakan (act) seseorang sesuai dengan norma hukum (bukan hanya sesuai aturan hukum) atau prinsip hukum. ${ }^{7}$ Kekuatan kajian hukum normatif terletak pada langkah-langkah ekwensial yang mudah ditelusuri ilmuwan hukum lainnya. Oleh karena itu langkah awal suatu kajian hukum normatif adalah penentuan pokok masalah secara tepat dan selanjutnya ditarik isu-isu hukum

Peter Mahmud Marzuki, 2013, Penelitian Hukum, Edisi Revisi, Cetakan Kedelapan, Kencana Prenada Media Group, Jakarta, hlm. 47. 
terkait atau komponen-komponen yang mendukungnya. ${ }^{8}$ Pendekatan yang digunakan dalam penelitian normatif ini adalah pendekatan undang-undang (statute approach), pendekatan konseptual (conceptual approach). ${ }^{9}$ Pendekatan undang-undang (statute approach) diperlukan guna mengkaji lebih lanjut mengenai ketentuan pidana Undang-Undang Pengampunan Pajak, adakah pertentangan antara Undang-Undang Pengampunan Pajak dengan undangundang lainnya. Pendekatan konseptual (conceptual approach), digunakan untuk mengkaji dan menganalisis kerangka pikir atau kerangka konseptual maupun landasan teoritis sesuai dengan tujuan penelitian ini yakni menemukan dan menjelaskan teori dan asas-asas hukum yang terkait dengan Pengampunan Pajak.

\section{HASIL DAN PEMBAHASAN}

1. Program Pengampunan Pajak Tahun 2016

Kebijakan Amnesti Pajak tahun 2016 dijalankan dengan dibentuknya undang-undang yaitu Undang-Undang Nomor 11 Tahun 2016 tentang Pengampunan Pajak. Hal ini sesuai dengan Pasal 23A Undang-Undang Dasar Negara Republik Tahun 1945 (UUD 1945). Berdasarkan ketentuan Pasal 23A UUD 1945 tersebut, maka pemerintah membuat kebijakan Amnesti Pajak dengan undang-undang.

Sebagaimana kebijakan Pengampunan Pajak sebelumnya yang diberi landasan hukum dalam bentuk Penpres Nomor 5 Tahun 1964 dan Keppres Nomor 26 Tahun 1984, perlakuan yang diatur dalam Undang-Undang Nomor 11 Tahun 2016 adalah memberikan pengampuan atas hutang pajak yang belum dibayar dengan kompensasi membayar uang tebusan dan terhadap laporan kekayaannya tidak akan dilakukan pengusutan fiskal dan tidak akan dijadikan sebagai bukti permulaan penyidikan dan penuntutan pidana pajak.

2. Batas Keberlakuan UU Nomor 11 Tahun 2016 Tentang Pengampunan Pajak

8 Philipus M. Hadjon, 1997, Pengkajian IImu Hukum, Paper, Penataran dan Lokakarya Sehari Menggagas Format Usulan dan laporan Penelitian Hukum Normatif, Fakultas Hukum Universitas Brawijaya, Malang.

${ }^{9}$ Ibid., h. 133. 
Undang-Undang Pengampunan Pajak tidak mengatur secara tegas kapan berakhirnya undang-undang tersebut. Tetapi di dalam Pasal 4 UndangUndang Pengampunan Pajak, dinyatakan secara tersirat bahwa UndangUndang Pengampunan Pajak hanya berlaku sampai dengan tanggal 31 Maret 2017. Hal ini sesuai dengan jangka waktu pemberian fasilitas Pengampunan Pajak yang terdiri dari 3 (tiga) tahap, yaitu tahap pertama dari tanggal 1 Juli 2016 sampai dengan 30 September 2016, tahap kedua dari tanggal 1 Oktober 2016 sampai dengan 31 Desember 2016, dan tahap ketiga dari tanggal 1 Januari sampai dengan tanggal 31 Maret 2017.

Batas keberlakuan Undang-Undang Pengampunan Pajak ini dipertegas oleh Mahkamah Konstitusi sebagaimana tercantum dalam Pertimbangan Putusan Mahkamah Konstitusi Nomor 57/PUU-XIV/2016 tentang Pengujian Undang-Undang Nomor 11 Tahun 2016 tentang Pengampunan Pajak, yang menyatakan sebagai berikut bahwa pemberlakuan Undang-Undang Nomor 11 Tahun 2016, sebagaimana diterangkan Presiden (Pemerintah) dan DPR, hanya dilakukan sekali dalam periode pelaksanaan kebijakan ini (one shot opportunity), sehingga pada tahun-tahun selanjutnya akan dilakukan pengenaan tarif normal dan penegakan hukum perpajakan secara konsisten. Artinya, setelah jangka waktu pelaksanaan Undang-Undang Nomor 11 Tahun 2016 ini berakhir maka UU KUP sebagaimana diatur dalam UU No 28 Tahun 2007 berlaku kembali. Oleh karena itu, tidaklah benar anggapan Pemohon bahwa dengan pemberlakuan Undang-Undang Nomor 11 Tahun 2016 berarti telah bergesernya sistem perpajakan. Selain itu, sebagai kebijakan khusus yang bersifat one shot opportunity tentu menjadi tidak tepat apabila diperbandingkan dengan keadaan normal, yang dengan cara itu lalu kemudian ditarik kesimpulan bahwa terdapat sejumlah besar kerugian negara jika dibandingkan dengan pemberlakuan Undang-Undang Perpajakan yang berlaku untuk keadaan "normal".

3. Batas Keberlakuan Sanksi Pidana UU Nomor 11 Tahun 2016 Tentang Pengampunan Pajak

Undang-Undang Pengampunan Pajak dapat dimanfaatkan agar harta yang diperoleh dari aktivitas yang tidak dilaporkan dapat diungkapkan secara sukarela sehingga data dan informasi atas harta tersebut masuk ke dalam 
sistem administrasi perpajakan dan dapat digunakan untuk pengawasan kepatuhan Wajib Pajak di masa yang akan datang. Dalam Undang-Undang Pengampunan Pajak perlindungan terhadap data dan informasi Wajib Pajak diatur dalam Bab $X$ tentang Manajemen Data dan Informasi, Data dan informasi yang bersumber dari Surat Pernyataan Harta dan lampirannya yang diterima dan dikelola oleh Kementerian Keuangan atau pihak lain yang berkaitan dengan pelaksanaan Undang-Undang ini tidak dapat dijadikan dasar penyelidikan, penyidikan, dan/atau penuntutan pidana terhadap Wajib Pajak

4. Keberlakuan Asas Preverensi Terhadap UU Pengampunan Pajak Dengan UU KUP

Peraturan perpajakan pada dasarnya merupakan ketentuan hukum administratif yang mengatur kewenangan negara untuk memungut pajak, oleh karena itu penerapan sanksi pidana hanya bersifat pelengkap. Dalam peraturan perpajakan telah ditetapkan mekanisme yang jelas tentang upaya yang dapat ditempuh terhadap Wajib Pajak yang melakukan pelanggaran hukum pajak. Kebijakan untuk menjatuhkan sanksi administratif berupa denda atau kenaikan harus lebih dahulu diterapkan, oleh karena itu Wajib Pajak yang karena kelalaian ataupun kesengajaan menyebabkan terjadinya pelanggaran pajak tidak mutlak harus diusut secara pidana. ${ }^{10}$

Sedangkan menurut Eddy O.S. Hiariej, menyatakan bahwa hukum pidana di bidang pajak merupakan ius singular yang mempunyai norma dan sanksi hukum yang bersifat administratif dan pidana, artinya penerimaan negara lebih diutamakan daripada penerapan sanksi pidana badan berupa perampasan kemerdekaan.Paradigma hukum pidana saat ini telah mengalami perubahan, yang semula berorientasi keadilan bersifat retributif (pembalasan) kini paradigmanya bergeser menjadi keadilan korektif, rehabilitatif, dan restoratif. Dari ketiga paradigma tersebut, dihubungkan dengan sifat ius singular dari hukum pidana pajak, maka dalam kaitan dengan dibebaskannya peserta Pengampunan Pajak setelah membayar uang tebusan dengan persentase tertentu dapat dibenarkan. Secara teori, hal itu dinamakan dengan

10 Suhanan Yosua, et.all., 2013, Hukum Pajak: Penerimaan, Kebijakan dan Instrumen Pengamanan dalam Rangka Perdagangan Bebas, In Media, Jakarta, hlm. 105. 
istilah pointless of punishment, yang artinya menghukum yang tidak perlu haruslah dihindari apabila tujuan dari Undang-Undang sudah tercapai. ${ }^{11}$

Hukum Pidana perpajakan mempunyai sifat dan karakteristik khusus terkait dengan tujuan penegakkannya. Tujuan pidana perpajakan bukan hanya semata-mata memberikan sanksi dan efek jera tetapi juga secara khusus untuk mendapatkan pemasukan penerimaan negara atas pajak terutang yang tidak atau belum dibayarkan beserta dengan sanksi administrasi atas keterlambatannya. Dalam hal sedang dilakukan penyidikan tindak pidana perpajakan terhadap Wajib Pajak, negara masih memberikan keadilan yang bersifat restoratif (restorative justice) yang tercermin dalam Pasal 44B ayat (1) dan ayat (2) UU KUP.

5. Pertentangan Pidana UU Pengampunan Pajak dengan UU Tindak Pidana Pencucian Uang

Selain penghentian proses penyidikan atau proses penuntutan sebagaimana diatur dalam Pasal 11 ayat (5) huruf d dan Pasal 6 UndangUndang Pengampunan Pajak, dalam Pasal 20 Undang-Undang Pengampunan Pajak, juga mencegah penyidikan dan penuntutan yang diatur dalam Undang-Undang Tindak Pidana Pencucian Uang. Pasal 20 pada intinya menyatakan bahwa data dari Surat Pernyataan dan lampirannya yang diterima dan disimpan oleh Kementerian Keuangan atau pihak lain yang berkaitan dengan pelaksanaan Undang-Undang ini tidak dapat dijadikan sebagai bukti penyelidikan, penyidikan, dan/atau penuntutan pidana terhadap Wajib Pajak yang mengikuti program amnesti pajak. Dengan demikian, telah terjadi pertentangan norma hukum antara ketentuan pidana Undang-Undang Pengampunan Pajak dengan Undang-Undang Tindak Pidana Pencucian Uang.

Dalam menghadapi antinomi hukum (konflik antar norma hukum) di atas, maka penyelesaiannya dengan menggunakan salah satu asas preferensi, yaitu asas lex specialis derogate legi generali, bahwa peraturan perundangundangan yang lebih khusus lebih kuat dibandingkan peraturan perundang-

11 Lihat Putusan Mahkamah Konstitusi Nomor 63/PUU-XIV/2016 tentang Pengujian UndangUndang Nomor 11 Tahun 2016 tentang Pengampunan Pajak [Pasal 1 angka 1, Pasal 3 ayat (3), Pasal 4, Pasal 21 ayat (2), Pasal 22, dan Pasal 23 ayat (2)]. 
undangan yang lebih umum. Namun, Undang-Undang Pengampunan Pajak dan Undang-Undang Tindak Pidana Pencucian Uang merupakan undangundang yang sama-sama bersifat khusus.

Pendapat Eddy O.S. Hiariej, yang menyatakan bahwa dalam perkembangan ilmu hukum -termasuk hukum pidana- atas lex specialis derogat legi generali tidak bisa menyelesaikan sengketa yuridis, dimana terjadi suatu perbuatan yang diancam lebih dari satu undang-undang yang dikualifikasikan sebagai bijzonder delic atau delik khusus atau tindak pidana khusus. Jika demikian halnya, maka yang digunakan adalah lex specialis sistematis sebagai derivat atau turunan dari asas lex specialis derogat legi generali. Menurut Remmelink, asas ini di Belanda dikenal dengan istilah specialis yuridikal atau specialis sistematikal, di samping logische specialiteit. $^{12}$

Berdasarkan asas lex specialis sistematis yang dikemukan oleh Eddy O.S. Hiariej diatas, maka jika terjadi suatu konflik norma hukum antara Undang-Undang Pengampunan Pajak dengan Undang-Undang Tindak Pidana Pencucian Uang, maka yang harusnya berlaku ialah Undang-Undang Tindak Pidana Pencucian Uang karena mengatur lebih lengkap dan rinci dalam kerangka ketentuan pidana khusus menyangkut keuangan negara. Sehingga jika terjadi kasus Wajib Pajak yang telah ikut Pengampunan Pajak yang hartanya berasal dari hasil tindak pidana pencucian uang, maka ketentuan manajemen data dan informasi dan ketentuan pidana Undang-Undang Pengampunan Pajak diabaikan dan harus dilakukan penyelidikan, penyidikan, dan penuntutan berdasarkan KUHAP, karena menurut Undang-Undang Tindak Pidana Pencucian Uang, jika terjadi tindak pidana pencucian uang, maka harus dilakukan penyelidikan, penyidikan, penuntutan, dan pemeriksaan di pengadilan berdasarkan KUHAP. Hal ini juga diperkuat oleh Mahkamah Konstitusi sebagaimana tercantum dalam Pertimbangan Putusan Mahkamah Konstitusi Nomor 57/PUU-XIV/2016 tentang Pengujian Undang-Undang Nomor 11 Tahun 2016 tentang Pengampunan Pajak.

12 Eddy O.S. Hiariej, 2014, Prinsip-Prinsip Hukum Pidana, Cahaya Atma Pustaka, Yogyakarta, hlm. 353. 


\section{PENUTUP}

Keberlakuan sanksi pidana dalam UU Pengampunan Pajak setelah tanggal 31 Maret 2017 tidak berlaku. Hal ini sesuai dengan asas perubahan perundangundangan sebagaimana diatur dalam Pasal 1 ayat (2) KUHP yang menyatakan apabila ada perubahan dalam perundang-undangan sesudah perbuatan pidana dilakukan, maka terhadap terdakwa diterapkan ketentuan pidana yang paling menguntungkannya. Terhadap pelaku tindak pidana sebagaimana diancam oleh Pasal 23 ayat (1) Undang-Undang Pengampunan Pajak, setelah masa berlakunya undang-undang tersebut berakhir, tidak dipidana karena harus diterapkan aturan yang paling ringan atau menguntungkan terhadap terdakwa. Berdasarkan asas lex specialis sistematis, jika terjadi pertentangan norma hukum antara UU Pengampunan Pajak dengan UU Tindak Pidana Pencucian Uang, maka yang berlaku ialah UU Tindak Pidana Pencucian Uang karena mengatur lebih lengkap dan rinci ketentuan pidana khusus. Hal ini diperkuat oleh Putusan Mahkamah Konstitusi Nomor 57/PUU-XIV/2016 tentang Pengujian Pengampunan Pajak.

\section{DAFTAR PUSTAKA}

\section{Buku}

Hiariej, Eddy O.S., 2014, Prinsip-Prinsip Hukum Pidana, Cahaya Atma Pustaka, Yogyakarta.

Ilyas, Wirawan B, dan Burton, Richard, 2014, Hukum Pajak: Teori, Analisis, dan Perkembangannya, Salemba Empat, Jakarta.

Marzuki, Peter Mahmud, 2013, Penelitian Hukum, Edisi Revisi, Cetakan Kedelapan, Kencana Prenada Media Group, Jakarta.

Pudyatmoko, Y. Sri, 2015, Memahami Keadilan di Bidang Pajak, Cahaya Atma Pustaka, Yogyakarta.

Soemitro, Rochmat dan Sugiharti, Dewi Kania, 2004, Asas dan Dasar Perpajakan 1, Refika Aditama.

Suandy, Erly, 2014, Hukum Pajak, Salemba Empat, Jakarta.

Yosua, Suhanan, et.all., 2013, Hukum Pajak: Penerimaan, Kebijakan dan Instrumen Pengamanan dalam Rangka Perdagangan Bebas, In Media, Jakarta.

\section{PERATURAN PERUNDANG-UNDANGAN}


Undang-Undang Dasar Negara Republik Indonesia Tahun 1945.

Undang-Undang Nomor 1 Tahun 1946 Tentang Peraturan Hukum Pidana jo. Undang-Undang Nomor 73 Tahun 1958 tentang Menyatakan Berlakunya Undang-Undang Nomor 1 Tahun 1946 Republik Indonesia Tentang Peraturan Hukum Pidana Untuk Seluruh Wilayah Republik Indonesia Dan Mengubah Undang-Undang Hukum Pidana (Lembaran Negara Republik Indonesia Nomor 127 Tahun 1958, Tambahan Lembaran Negara Republik Indonesia Nomor 1660 Tahun 1958).

Undang Nomor Nomor 8 Tahun 1981 tentang Hukum Acara Pidana (Lembaran Negara Republik Indonesia Tahun 1981 Nomor 76, Tambahan Lembaran Negara Republik Indonesia Nomor 3209).

Undang-Undang Nomor 28 Tahun 2007 Tentang Perubahan Ketiga Atas UndangUndang Nomor 6 Tahun 1983 Tentang Ketentuan Umum Dan Tata Cara Perpajakan (Lembaran Negara Republik Indonesia Tahun 2007 Nomor 85, Tambahan Lembaran Negara Republik Indonesia Nomor 4740).

Undang-Undang Nomor 8 Tahun 2010 Tentang Pencegahan dan Pemberantasan Tindak Pidana Pencucian Uang (Lembaran Negara Republik Indonesia Tahun 2010 Nomor 122, Tambahan Lembaran Negara Republik Indonesia Nomor 5164).

Undang-Undang Nomor 11 Tahun 2016 Tentang Pengampunan Pajak (Lembaran Negara Republik Indonesia Tahun 2016 Nomor 131, Tambahan Lembaran Negara Republik Indonesia Nomor 5899).

\section{SUMBER LAIN}

Hadjon, Philipus M., 1997, Pengkajian Ilmu Hukum, Paper, Penataran dan Lokakarya Sehari Menggagas Format Usulan dan Laporan Penelitian Hukum Normatif, Fakultas Hukum Universitas Brawijaya, Malang.

Putusan Mahkamah Konstitusi Nomor 57/PUU-XIV/2016 tentang Pengujian Undang-Undang Nomor 11 Tahun 2016 tentang Pengampunan Pajak.

Putusan Mahkamah Konstitusi Nomor 63/PUU-XIV/2016 tentang Pengujian Undang-Undang Nomor 11 Tahun 2016 tentang Pengampunan Pajak. 